\title{
Biological Considerations IN MARINE ENCLOSURE EXPERIMENTS: CHALLENGES AND REVELATIONS
}

\author{
By Candace A. Oviatt
}

$\mathrm{L}$ tated that components of estuarine systems be considered in isolation from one another whether in the laboratory or field. Hence, biological disciplines usually have specialized to a single area or process. By contrast, enclosure or mesocosm experiments force the study of all components interacting together. Since they are no longer studied in isolation, these components can be observed to behave in unpredicted, interactive patterns.

Since 1976, experiments have been conducted in enclosures at the University of Rhode Island. These enclosures model various aspects of the coastal environment. They are $5 \mathrm{~m}$ deep, to maintain a heterotrophic benthos, $13 \mathrm{~m}^{3}$ in volume so zooplankton can be sampled without impacting population abundances, and $2.62 \mathrm{~m}^{2}$ in area so that the benthos may be sampled with minor impact over annual cycles. The simplicity of the enclosures together with flexibility in design and use has led to their long life. Mixing can be vertical, horizontal, intermittent, or constant at any reasonable intensity. The enclosures are sufficiently deep to allow thermal and salinity stratification to be simulated. Experiments can therefore be conducted on marine systems exhibiting different degrees of stratification. Sea water can flow constantly, or intermittently, or not at all for whatever turnover is deemed appropriate. Sediments can be present or absent; when present, they can come from various sources. Sunlight can be natural or shaded or ultraviolet enhanced.

As with any new approach, the outcome of early experiments was rarely predicted correctly. Manipulations, such as installing the sediment community, often had greater effects than experimental treatments. Along the way insights have been gained on interactions between ecosystem components. Some of these insights, serendipitously discovered, were

C. A. Oviatt, University of Rhode Island, Graduate School of Oceanography, Narragansett Bay Campus, Narragansett, Rhode Island 02882-1197, USA the necessary outcome of having to design models of living systems. Other insights were revealed from controlled manipulations designed to test particular hypotheses. Some came from the rare opportunity to observe ecosystem operation in multiple systems side by side. With multiple enclosures, a gradient of exposure or dose can be established and controlled to a degree not possible in the field. Whether planned or unexpected, interactions observed during enclosure experiments provoke new hypotheses and insights on coastal ecosystems.

Five types of experiments can be conducted in enclosures:

1) Experiments to measure budgets of selected materials. In the field, budgets of materials always include unknowns or values calculated by difference. For experiments in enclosures, all phases and compartments can be measured, such as, rates of breakdown, disappearance from the water column, mixing into sediments, and fluxing back from sediment, perhaps in another form. These data can be used to budget substances accurately under nearly natural conditions allowing the budgets to be extrapolated to the field.

2) Measurements of dose-response relationships of whole ecosystems to nutrients or contaminants. For experiments on impacts we have examined the effects of hydrocarbons and eutrophication in enclosures. Dose can be related to response of the whole system and components of the system. Unlike the field situation, a control treatment with an identical physical configuration but no dose, is always possible.

3) Measurements of the response to natural variables such as temperature, light, turbulence or salinity. This type of experiment uses manipulation in which some physical variable is changed, e.g., stratification, mixing intensity, salinity, sediment or temperature. These types of experiments increase our understanding of how the natural system operates.

4) Intercalibration experiments. The contained water mass provides opportunities for intercalibra-
. . interactions

observed during

enclosure experiments

provoke new

hypotheses and

insights . . . 
tion of methods for measuring primary and secondary productivity. For example, bottle incubations with ${ }^{14} \mathrm{C}$, oxygen, ${ }^{18} \mathrm{O}$, or carbon dioxide, can be intercompared with whole enclosure measures of primary production using some of the same variables. Intercalibration experiments can also be conducted for the various measures of zooplankton secondary production.

5) Measuring the growth and survival of larval forms. Enclosures are useful for measuring the growth and survival of larval forms under a variety of natural conditions. Larval fish like cod, winter flounder, menhaden, anchovy and others have shown good survival and growth in enclosures.

While many mesocosm designs are possible, some organisms and processes are better studied in the laboratory or the field. Most mesocosms have physical constraints that limit their usefulness for studying large invertebrates, fish, mammals, and birds on the one hand, and single species of bacteria and specific physiological processes of single species on the other hand. They are generally not useful for studying deep sea environments or strongly advective environments. Ideal ecological studies would use a combination of laboratory and mesocosm experiments, field studies, and modeling approaches.

From the beginning numerous comparisons were made between our enclosures and the parent ecosystem, Narragansett Bay. Every attempt was made to measure how poorly or how well the mesocosms simulated nature. Comparisons of phytoplankton, zooplankton, benthic fauna, nutrient cycles, and rates, such as primary production, showed good agreement between the enclosures and nature. Some of the differences included enhanced vertical mixing, a thicker surface film at the air-water interface, lack of horizontal advection, lack of large invertebrates and large fish, and wall fouling in the mesocosms. The mesocosms are simplified models of nature and agreements and disagreements with nature continue to be defined in every new experiment.

This article summarizes major biological interactions exemplified in a few experiments. Some of them were interactions that were already suspected to be important but were untested. Others were unexpected. These interactions revealed or clarified structure and function of natural systems.

\section{Competition for Nutrients: Wall Flora Versus Phytoplankton}

Artifacts of enclosure studies such as wall-surface-to-volume ratios can reduce the realism of a model of a pelagic system. The interaction between wall flora and phytoplankton vividly illustrates the competition between these communities. Wall flora must be controlled to permit pelagic phytoplankton to dominate. All original experimental design considerations for enclosure experiments called for wall scrubbing to maintain a pelagic community. Every time the wall scrubbing schedule was not strictly maintained, a rapid succession changed the pelagic system to a tide pool system. First bacteria, ciliates, and benthic diatoms would spread over the surfaces (Caron and Sieburth, 1981) then macroalgae (including tough to remove Ralfsia sp.), limpets, gastropods, and amphipods. As this succession developed, the water column would become increasingly clear indicating the greater efficiency with which the wall communities sequestered nutrients. Even with rigorous cleaning we documented that 2 to $20 \%$ of the primary production occurred on the walls of the enclosures (Oviatt et al., 1986b).

Thus, from the beginning the designers of mesocosm experiments knew that plants on all lighted solid surfaces could out-compete a pelagic plant community. Even with that knowledge we outwitted ourselves in one major experiment. The experiment was designed to illustrate which nutrients were limiting in marine coastal waters and mimicked the experiments in Canada which so convincingly indicated phosphorus as the limiting nutrient in those freshwater lakes (Schindler, 1974). Nutrients were added to mesocosms in two doses, once in June and again in October.

During the first addition, blooms of phytoplankton occurred in the nitrogen-enhanced and the nitrogen- and phosphorus-enhanced treatments but not in the controls or treatments with phosphorus added alone (Fig. 1). System production as measured by dawn-to-dusk changes in oxygen concentration varied from zero to usually $<5 \mathrm{~g} \mathrm{O}_{2} \mathrm{~m}^{-2} \mathrm{~d}^{-1}$ in control and phosphorus treatments, whereas it exceeded $10 \mathrm{~g} \mathrm{O}_{2} \mathrm{~m}^{-2} \mathrm{~d}^{-1}$ several times in the nitrogen and nitrogen plus phosphorus treatments. The second time the nutrients were added there was minimal response in water column parameters in nitrogen treatments although the nutrients declined in the water column. After the October addition, system production was usually much $<3 \mathrm{~g} \mathrm{O}_{2} \mathrm{~m}^{-2}$ $\mathrm{d}^{-1}$ in all treatments (Fig. 1).

The evidence was convincing that nitrogen was the limiting nutrient during the first nutrient treatment additions. But what happened following the October additions? A $1 \mathrm{~m}^{2}$ patch of enclosure wall was left uncleaned throughout the experiment to provide an undisturbed surface for measurements of nitrogen fixation. In general these acetylene reduction measurements showed that after August up to $1-5 \mathrm{mg} \mathrm{N} \mathrm{m}^{-2} \mathrm{~d}^{-1}$ were fixed in control and phosphorus nutrient treatments although not much fixation occurred in other treatments (J. Cole, personal communication). We observed increasingly dense macroalgae in the uncleaned patches in all treatments. Algae ultimately stretched more than halfway across the surface of the nitrogen treatments and nitrogen- and phosphorus-enhanced enclosures. The macroalgae could have absorbed the nutrients forming a large biomass but contributing 


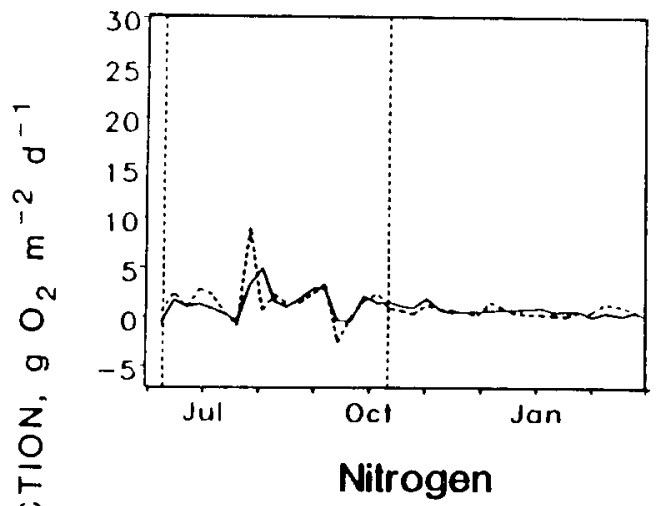

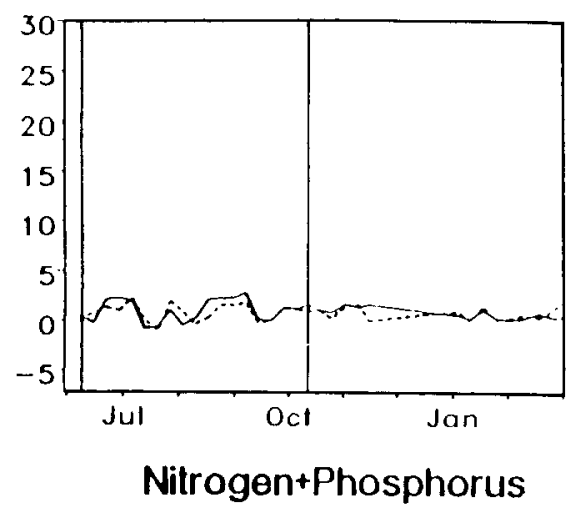

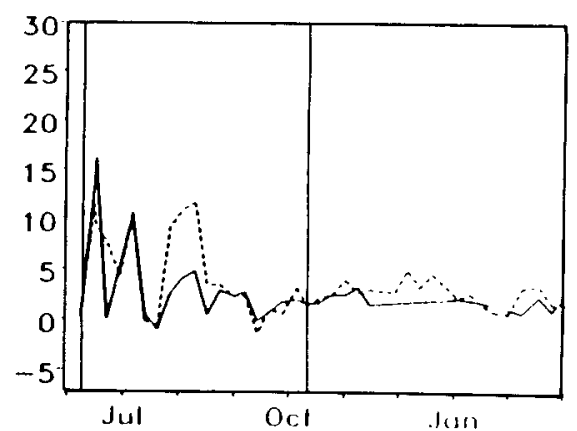

Fig. 1: System production in replicates of control and nutrient treatments from June 1982 to April 1983. Solid vertical lines indicate times of nutrient additions and dotted lines indicate corresponding times in controls.

less to system production than did phytoplankton in the first addition (Fig. 1).

A $1 \mathrm{~m}^{2}$ patch was thought too small to affect the experiment, but we probably underestimated its nutrient absorbing capacity. If the patch contained 2 $\mathrm{kg}$ of macroalgae (or $200 \mathrm{~g} \mathrm{C}$ or $16.7 \mathrm{~mol} \mathrm{C}$ ) then assuming a Redfield Ratio, it could have contained $2.5 \mathrm{~mol}$ of nitrogen. In the nitrogen addition treatments, we added $1.6 \mathrm{~mol}$ of nitrogen to the enclosure. The patch could have taken up this amount of nutrient. Measurable increases up to $3 \mathrm{~g} \mathrm{O}_{2} \mathrm{~m}^{-2} \mathrm{~d}^{-1}$ did occur in October in the nitrogen and nitrogen plus phosphorus treatments while smaller variations occurred in control and phosphorus treatments. The hypothesis to be tested in future experiments is whether nutrients taken up by macroalgae result in smaller increases in production than would have been caused by phytoplankton. Recently, the Rhode Island Sea Grant Program has been testing interactions of this nature between eelgrass beds and phytoplankton in experimental enclosures ( $\mathrm{S}$. Nixon, personal communication).

\section{Phytoplankton Self-Shading}

The question has arisen as to why the planktonic primary productivity of coastal areas is constrained to a fairly narrow range (roughly 100-500 $\mathrm{g} \mathrm{C} \mathrm{m}^{-2} \mathrm{y}^{-1}$ ) (Nixon and Pilson, 1983). In adjacent shallower waters with the same nutrient regime seagrass meadows, macroalgae, and marsh grasses attain a much greater harvestable productivity. Explanations include the following: 1) the suggestion that the rate limiting process which slows primary productivity is the heterotrophic rate of regeneration of nutrients (Nixon and Pilson, 1983) and 2) the advantage to macrophytes of nutrient supply by advection versus supply to phytoplankton cells by shear and diffusion (Mann and Lazier, 1991). However, a nutrient-addition experiment provided evidence that self-shading by phytoplankton may limit their primary productivity and ability to utilize available nutrients. While self-shading has long been recognized (e.g., Kremer and Nixon, 1978), the belief that it explains the narrow range of primary productivity in coastal waters is new.

In a nutrient addition experiment, a geometric progression of nutrients (1X, 2X, 3X, 4X, 8X, $16 \mathrm{X}, 32 \mathrm{X}$ ) was added to seven individual enclosures. The experiment was designed to define the assimilative capacity of well-mixed estuarine systems for nutrients and to find the threshold for negative effects such as low oxygen conditions. Three enclosures acted as controls and received no additional nutrients. The $1 \mathrm{X}$ enclosure (equivalent to sewage nutrient input to Narragansett Bay) received $2.88 \mathrm{mmol} \mathrm{N}, 0.23 \mathrm{mmol} \mathrm{P}$ and $0.19 \mathrm{mmol}$ Si $\mathrm{m}^{-2} \mathrm{~d}^{-1}$ for a ratio of $12 \mathrm{~N}: 1.0 \mathrm{P}: 0.9 \mathrm{Si}$. The experiment was maintained over 28 mo from June 1981 to September 1983. For a 32-fold increase in nutrients, net water column production increased
. . a nutrient-

addition experiment

provided evidence

that self-shading by

phytoplankton may

limit their primary

productivity and

ability to utilize

available nutrients. 
. . primary

production in the nutrient gradient appeared to be sensitive to self-shading. only by a factor of 3.5 over control values (Oviatt et al., 1986a). On an annual basis, controls produced about $700 \mathrm{~g} \mathrm{O}_{2} \mathrm{~m}^{-2} \mathrm{y}^{-1}$ and the $32 \mathrm{X}$ treatment produced about 2,400 $\mathrm{g} \mathrm{O}_{2} \mathrm{~m}^{-2} \mathrm{y}^{-1}$ (Fig. 2).

Our experiment illustrated that more nutrients always resulted in greater productivity. Thus in one sense nutrients were limiting but high nutrients still did not result in productivities equivalent to shallow-growing macrophytes. Furthermore most of the added nutrients were flushed out of the system unutilized by phytoplankton (Nowicki and Oviatt, 1990). The greater phytoplankton productivity resulted from prolongation of the winterspring blooms into summer and higher peaks of productivity from winter through summer in nutrient treatments (Oviatt et al. 1986a; Fig. 3). By contrast, control treatments showed a winter peak, a spring trough, and a summer peak.

Overall, primary production in the nutrient gradient appeared to be sensitive to self-shading. On an annual basis phytoplankton production to biomass ratios decreased by a factor of 2.5 up the nutrient gradient and were negatively correlated with increasing water column extinction coefficients from 1.10 to $1.75, r=-0.85$ (Oviatt et al., 1989). On a seasonal basis, self-shading imposed by elevated diatom concentrations reduced winter-spring levels of primary production compared to summer blooms by pico- and nanophytoplankton. Elevated grazing rates during summer reduced diatom flora

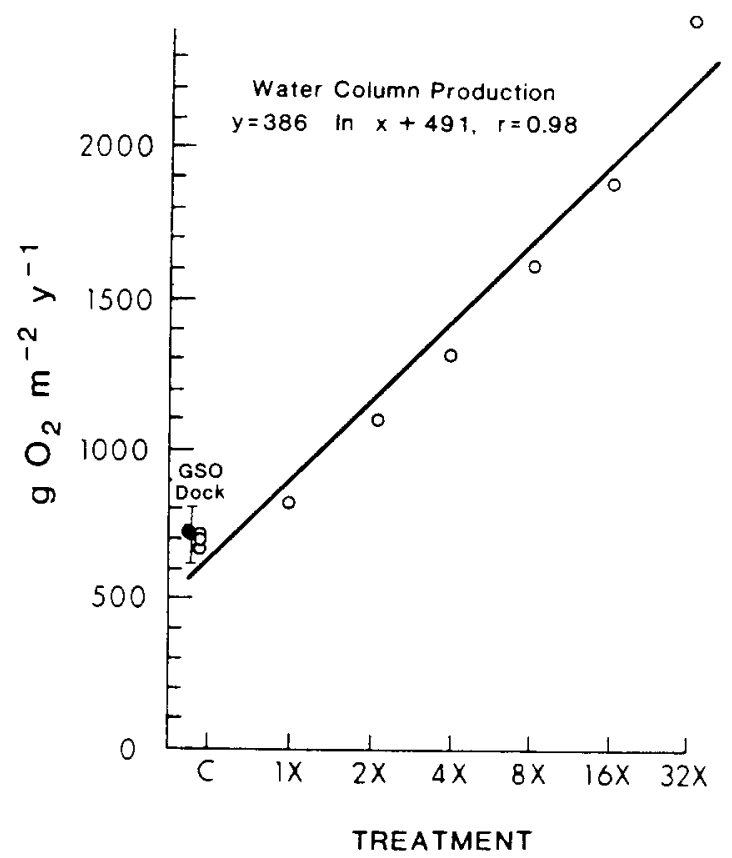

Fig. 2: Annual values for water column net production versus nutrient loading, shown for treatment level and as a function of nitrogen addition. Data from lower Narragansett Bay at the Graduate School of Oceanography (GSO) dock (opaque circle and standard deviation bars) are shown for comparison.
Table 1

Diatom concentrations (cells $\mathrm{L}^{-1} \times 10^{6}$ ) during winter and summer for controls ( $\overline{\mathrm{X}}$ three) and two nutrient treatments to exemplify the difference between seasons during 1982

\begin{tabular}{lccr}
\hline & Control & $4 \mathrm{X}$ & $16 \mathrm{X}$ \\
\hline January, February, March & 2.24 & 9.53 & 16.66 \\
June, July, August & 0.79 & 0.37 & 0.10 \\
\hline
\end{tabular}

and their self-shading effect on primary production (Table 1). Thus chlorophyll concentrations increased from winter to spring and decreased in summer (Fig. 3). These observations provide evidence that the productivity of coastal water will be constrained to a low range due to self-shading by phytoplankton.

\section{Competition for Phytoplankton}

Usually, zooplankton are considered to be the main grazers on phytoplankton but mesocosm experiments have revealed that benthic grazers under a well-mixed water column may be more important in limiting phytoplankton biomass. During summer, temperature-regulated grazing rates of both planktonic and benthic fauna reach their maximum. Pelagic copepods have the highest grazing rates on a per gram basis of pelagic and benthic grazers (Beatty, 1991). On an individual basis, benthic fauna of much greater weight than zooplankton (amphipods, spionid polychaetes, and tunicates) have the highest rates. In the nutrient addition ex-
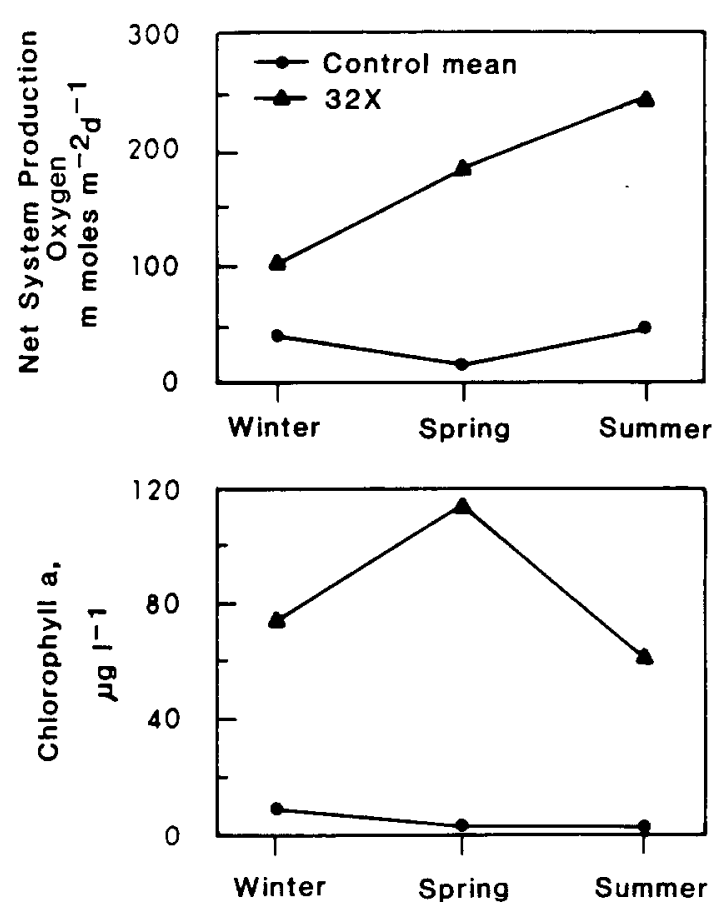

Fig. 3: Daytime system production and phytoplankton biomass (chlorophyll a) averaged by season for the control (mean of 3 ) and the $32 X$ treatment. Other treatments (not shown) fall within these envelopes. 


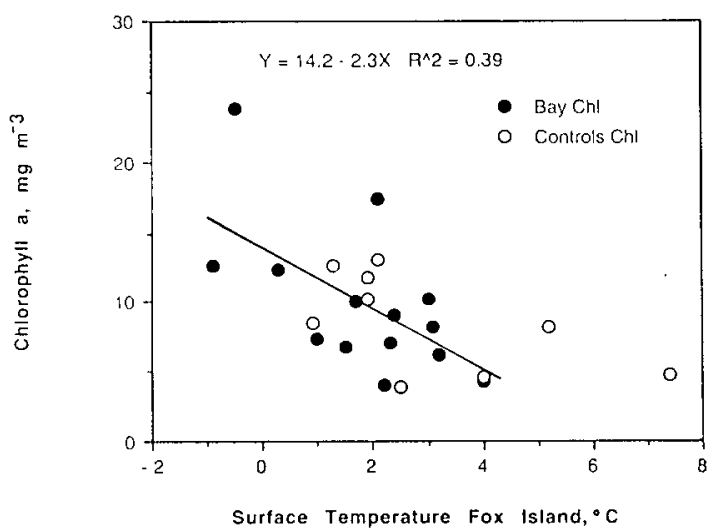

Fig. 4: Opaque points and regression line: mean monthly chlorophyll concentrations during the winter-spring diatom bloom at the Graduate School of Oceanography dock as a function of mean monthly surface water temperature at Fox Island from 1977 to 1990 (temperature data courtesy of H.P. Jeffries). The coldest year, 1977, had the highest chlorophyll value and the warmest year, 1983, had the lowest chlorophyll value. Note the span of average temperature for this 13-year period was about $6^{\circ} \mathrm{C}$. Open points: data from control mesocosms show a similar trend although coarse temperature control $\left( \pm 2^{\circ} \mathrm{C}\right)$ and a management strategy to prevent freezing precludes one-to-one agreement. Data are from 1977 to 1983 and 1985 when year-round experiments were conducted.

periment, contrary to the expected, pelagic copepods failed to increase in abundance with nutrientinduced phytoplankton increases (Sullivan and Banzon, 1990). Only meroplankton increased and of the meroplankton, polychaete larvae dominated. When these larvae set, macrobenthic abundance increased from 10,000 to 200,000 spionid polychaetes $\mathrm{m}^{-2}$ with no corresponding increase in infaunal (mainly bivalve) deposit-feeders.

Feeding rate experiments showed that benthic spionid polychaetes, feeding directly on water column phytoplankton with their tentacles, could exert a significant pressure on phytoplankton biomass and reached their greatest impact on phytoplankton larger than $10 \mu \mathrm{m}$ (Taghon et al., 1980; Beatty, 1991). In a well-mixed $5 \mathrm{~m}$ deep water column like the experimental enclosures, 100,000 spionid polychaetes $\mathrm{m}^{-2}$ can remove $50 \%$ of the phytoplankton each day (Beatty, 1991). A doubling to 200,000 polychaetes $\mathrm{m}^{-2}$ can remove almost $100 \%$ of the phytoplankton each day.

These observations provide evidence that benthic grazers control the diatom flora in the overlying water column and prevent a fall bloom in shallow well-mixed coastal waters. In stratified temperate systems, the seasonal pattern of phytoplankton productivity shows a winter-spring diatom bloom and a second diatom bloom in the fall (e.g., Day et al., 1989). In well-mixed Narragansett Bay this fall bloom often fails to occur except in unusually cold years (Oviatt, 1985). During the nutrient addition experiment, productivity nearly always declined to annual lows in autumn except in treatments where benthic grazers had been eliminated (Oviatt et al., 1986a). In 16X and $32 \mathrm{X}$ treatments where fall productivity remained high, the benthic fauna had been severely reduced by Crangon shrimp in 16X and anoxia in $32 \mathrm{X}$.

In warm years, elevated benthic grazing rates may also reduce the winter-spring bloom in wellmixed waters. During 1982, low productivity and biomass of phytoplankton continued from fall into winter in treatments with normal abundances of benthic fauna (Oviatt et al., 1986a). In general during the 1980s, warm winters were correlated with less intense winter-spring diatom blooms in the enclosures and in Narragansett Bay (Fig. 4). The warm El Niño year of 1983 had the smallest winter-spring diatom bloom of that decade. In the benthos, bivalves, amphipods, and spionid polychaetes were abundant, exerting probable grazing pressure on phytoplankton. In the experimental systems and perhaps, in Narragansett Bay, they may have been responsible for the negligible winter-spring diatom blooms in these warm winters. The question arises as to what effect this loss of food might have on the infaunal deposit feeding community. Other enclosure experiments have shown that in cold winters, the ungrazed diatoms fall to the benthos (Riebesell, 1989); this organic matter becomes buried in the sediment and available as stored food for benthic infauna throughout the summer (Rudnick and Oviatt, 1986). The fate of this community after warm winters with no bloom remains in question (but see Grassle et al., 1985).

\section{Competition for Zooplankton}

The lack of a zooplankton response in the nutrient gradient experiment stimulated searches for an explanation and the question as to whether this pattern occurs in nature. Benthic grazers may have been able to out compete zooplankton for food, but on a weight-specific basis, pelagic copepods

Table 2

Comparison of summer filtering rate (FR) $\left(20^{\circ} \mathrm{C}\right)$

for pelagic and benthic grazers (From Beatty, 1991)

\begin{tabular}{|c|c|c|c|c|}
\hline $\begin{array}{l}\text { Species } \\
\text { or group }\end{array}$ & $\begin{array}{l}\text { Ind. FR } \\
\text { ind }{ }^{-1} \mathrm{~d}^{-1}\end{array}$ & $\begin{array}{c}\text { Weight } \\
\text { C-wt ind }\end{array}$ & $\begin{array}{l}\text { Wt spec. FR } \\
\mathrm{L} \mathrm{g} \mathrm{C}^{-1} \mathrm{~h}^{-1}\end{array}$ & $\begin{array}{l}\text { References } \\
\text { for indiv. }{ }^{a} \\
\text { FR/indiv. wt }\end{array}$ \\
\hline \multicolumn{5}{|l|}{ Pelagic } \\
\hline Copepods (Acartia tonsa) & $50 \mathrm{ml}$ & $5 \mu \mathrm{g}$ & 417 & $\begin{array}{l}\text { Durbin et al., } 1990^{a} \\
\text { Cloern, } 1982^{b}\end{array}$ \\
\hline \multicolumn{5}{|l|}{ Benthic } \\
\hline $\begin{array}{l}\text { Amphipods and Spionid } \\
\text { polychaetes }\end{array}$ & $25 \mathrm{ml}$ & $25 \mu \mathrm{g}$ & 42 & $\begin{array}{l}\text { Beatty, } 1991^{a, b} \\
\text { Randlov and Riisgard, }\end{array}$ \\
\hline $\begin{array}{l}\text { Molgula manhattensis } \\
\quad \text { (ascidian) }\end{array}$ & $14.4 \mathrm{~L}$ & $18 \mathrm{mg}$ & 33 & $1979^{4}$ \\
\hline
\end{tabular}

. . benthic grazers

control the diatom

flora in the overlying

water column and

prevent a fall

bloom . . . 
were more efficient grazers than the benthos (Table 2). The productivity of copepods as measured by egg production rates did increase in treatments of the nutrient gradient (Sullivan and Banzon, 1990). Thus by inference mortality rates of zooplankton must have been higher in nutrient treatments, and a search for benthic predators of zooplankton began.

One pattern became clear: when there was no benthos, zooplankton and other pelagic forms were more successful (Doering et al., 1989; Sullivan et al., 1991). In the nutrient gradient experiment some treatments had large increases in the shrimp Crangon septemspinosa which preyed upon benthic fauna. When the shrimp increased, the benthic biomass decreased with polychaetes disappearing first. Total biomass of benthic species reached low levels compared to treatments without shrimp. For example, in the $16 \mathrm{X}$ treatment, large numbers of shrimp reduced benthic biomass to about $3 \mathrm{~g} \mathrm{C} \mathrm{m}^{-2}$ in the summer of 1983, whereas the $8 \mathrm{X}$ treatment, with no shrimp, had a biomass of $30 \mathrm{~g} \mathrm{C} \mathrm{m}^{-2}$. In treatments with
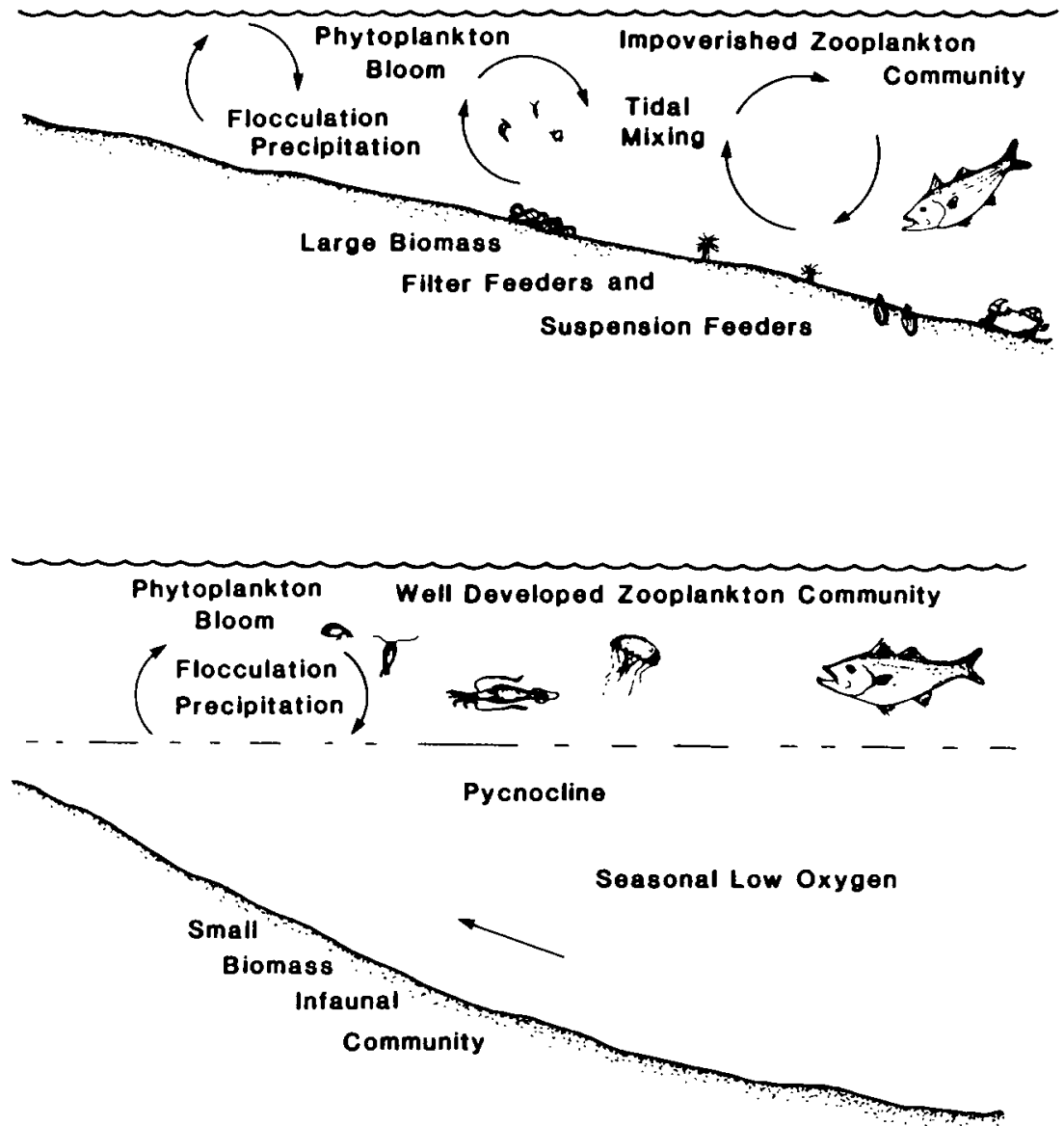

Fig. 5: Schematic representation of two extremes hypothesized for structure and function of well-mixed versus stratified systems, indicating benthic dominance in the former and water column dominance in the latter. Filter feeding bivalves feed on particles in the water column; suspension feeders feed on particles in the water column and on the surface of the sediment. Infaunal benthic species feed on inorganic detritus in the sediment. reduced benthic biomass, zooplankton numbers increased and became consistent with the nutrient stimulated egg production by copepods (Sullivan and Banzon, 1990).

One zooplankton predator in the benthos was identified as the mud anemone Ceriantheopsis americanus. Gut content analyses from the field revealed that mud anemones fed on both harpacticoid and calanoid copepods (Holohan, 1993). Feeding rate studies indicated maximum capture rates of 25 calanoid copepods per hour during mixing versus maximum capture rates of about 7 copepods per hour under static conditions (Sullivan et al., 1991). Other benthic predators may have been present also. Amphipods, mysids, and filter feeders were suspects.

In one experiment the sediment community was deliberately omitted to observe the response of the pelagic community and to simulate a stratified water column (Doering et al., 1989). The response was robust. Not only were zooplankton copepods more abundant but predaceous copepods, ctenophores, arrow worms, and larval fish were evident in treatments with no benthos (Sullivan et al., 1991). In systems with a benthos, primary productivity was high due to benthic flux of remineralized nutrients, but the water column trophic levels were impoverished and benthic macrofauna dominated biomass in the system. Within a month, in systems without a benthos, zooplankton biomass was elevated even though primary production was low and several copepod predators were present. Juvenile menhaden, which entered as larvae in the seawater flowing to the enclosures, rapidly grew to a size where their predation reduced copepods to low abundances (Doering et al., 1989). When the fish were winter-killed by low temperatures, copepod abundances rebounded (Sullivan et al., 1991).

The role of the benthos in controlling water column activity has been revealed in field studies and enclosure experiments. Many field studies have shown the impact of benthic remineralization on nutrients (Nixon and Pilson, 1983), of bivalves on phytoplankton (Doering et al., 1986), of macrofauna on zooplankton (Daborn, 1986) and how the benthos may exert a damping effect on eutrophication (Cloern, 1982; Officer et al., 1982). In enclosure studies with a well mixed water column and a benthos, an enriched phytoplankton but a depauperate water column zooplankton community results; when a benthos is absent or the system is stratified, copepods become abundant and ctenophores, arrow worms, jellyfish, and larval fish appear to prey on an abundant pelagic food supply. These studies together suggest benthic dominance of shallow, well mixed coastal areas and water column dominance of deeper, stratified marine waters (Fig. 5). 


\section{Acknowledgments}

Dr. Barbara Sullivan Watts, Dr. David Taylor, Dr. Aimee Keller, Dr. Peter Doering and two unknown reviewers kindly reviewed this paper and suggested many improvements. The experiments cited were supported by the Environmental Protection Agency Cooperative Agreements CR807795-02, CR810265-01, CR810265-02, CR810265-03, CR812487-01, CR812487-02, and CR812487-03. Other support was obtained from the Andrew Mellon Foundation.

\section{References}

Beatty, L.L. 1991: The response of benthic suspension feeders and their grazing impact on phytoplankton in eutrophied coastal ecosystems. Ph.D. thesis, University of Rhode Island $352 \mathrm{pp}$.

Caron, D.A. and J. McN. Sieburth, 1981: Diel flux of dissolved carbohydrate in a salt marsh and a simulated estuarine ecosystem. Marine Biology, 63, 175-187.

Cloern, J.E. 1982: Does the benthos control phytoplankton biomass in South San Francisco Bay? Mar. Ecol. Prog. Ser., 9, 191-202.

Daborn, G.R. 1986: Effects of tidal mixing on the plankton and benthos of estuarine regions of the Bay of Fundy. In: Tidal Mixing and Plankton Dynamics. M.J. Bowman, C.M. Yentsch, W.T. Peterson, eds. Lect. Notes Coastal Estaurine Studies. 17, 390-413.

Day, J.W., Jr., C.A.S. Hall, W. Michael Kemp and A. YanezArancibia, 1989: Estuarine Ecology, John Wiley \& Sons, New York, $153 \mathrm{pp}$.

Doering, P.H., C.A. Oviatt, L.L. Beatty, V.F. Banzon, R. Rice, S.P. Kelly, B.K. Sullivan, J.B. Frithsen, 1989: Structure and function in a model coastal ecosystem: silicon, the benthos and eutrophication. Mar. Ecol. Prog. Ser., 52, 287-299.

C.A. Oviatt and J.R. Kelly, 1986: The effects of the filter feeding clam Mercenaria mercenaria on carbon cycling in experimental marine mesocosms. J. Mar. Res., 44, 839-861.

Durbin, A.G., E.G. Durbin and E. Wlodarczyk, 1990: Diel feeding behavior in the marine copepod Acartia tonsa in relation to food availability. Mar. Ecol. Prog. Ser., $68,23-45$.

Grassle, J.F., J.P. Grassle, L.S. Brown-Leger, R.F. Petrecca and N.J. Copley. 1985: Subtidal macrobenthos of Narragansett Bay. Field and mesocosm studies of the effects of eutrophication and organic input on benthic populations. In: Marine Biology of Polar Regions and Effects of Stress on Marine Organisms, J.S. Gray and M.E. Christiansen. eds. Wiley, New York, 421-434

Holohan, B., 1993: Population density and grazing of Ceriantheopsis americanus in Narragansett Bay. Masters thesis, Graduate School of Oceanography, University of
Rhode Island, $97 \mathrm{pp}$.

Kremer, J.N. and S.W. Nixon, 1978: A coastal marine ecosystem simulation and analysis. Springer-Verlag, New York. 217 pp.

Mann. K.H. and J.R.N. Lazier, 1991: Dynamics of Marine Ecosystems Biological-Physical Interactions in the Oceans. Blackwell Scientific Publications. Boston, MA, $9-60$.

Nixon, S.W. and M.E.Q. Pilson, 1983: Nitrogen in estuarine and coastal marine ecosystems. In: Nitrogen in the $\mathrm{Ma}$ rine Environment, E.J. Carpenter, D.G. Capone, eds. Academic Press, New York, 565-648.

Nowicki, B.L. and C.A. Oviatt, 1990: Are estuaries traps for anthropogenic nutrients? Evidence from estuarine mesocosms. Mar. Ecol. Prog. Ser., 66, 131-146.

Officer, C.B., T.J. Smayda. and R. Mann, 1982: Benthic filter feeding: a natural eutrophication control. Mar. Ecol. Prog. Ser., 9, 203-210.

Oviatt, C.A., 1985: Annual and monthly biological variability in Narragansett Bay, a temperate estuarine system. Estuarine Research Federation, University of New Hampshire. Abstract.

A.A. Keller, P.A. Sampou and L.L. Beatty, 1986a: Patterns of productivity during eutrophication: a mesocosm experiment. Mar. Ecol. Prog. Ser., 28, 69-80.

. P. Lane, F. French III, P. Donaghay, 1989: Phytoplankton species and abundance in response to eutrophication in coastal marine mesocosms. J. Plankton Res. 11; 1223-1244.

,D.T. Rudnick, A.A. Keller, P.A. Sampou and G.T. Almquist, 1986b: A comparison of system $\mathrm{CO}_{2}$ and $\mathrm{CO}_{2}$ ) and $\mathrm{C}-14$ measurements of metabolism in estuarine mesocosms. Mar. Ecol. Prog. Ser., 28, 57-67.

Randlov, A. and H.U. Riisgard, 1979: Efficiency of particle retention and filtration rate in four species of ascidians. Mar. Ecol. Prog. Ser., I, 55-59.

Riebesell, U., 1989: Comparison of sinking and sedimentation rate measurements in a diatom winter spring bloom. Mar. Ecol. Prog. Ser., 54, 109-119.

Rudnick, D.T. and C.A. Oviatt, 1986: Seasonal lags between organic carbon deposition and mineralization in marine sediments. J. Mar. Res., 44, 815-837.

Schindler, D.W., 1974: Eutrophication and recovery in experimental lakes: implications for lake management. Science, 184, 897-899.

Sullivan, B.K. and V. Banzon, 1990: Food limitation and benthic regulation of populations of the copepod Acartia hudsonica Pinhey in nutrient-limited and nutrient-enriched systems. Limnol. Oceanogr., 35, 1618-1631.

.P.H. Doering, C.A. Oviatt, A.A. Keller, J.B. Frithsen, 1991: Interactions with the benthos alter pelagic food web structure in coastal waters. Can. J. Fish. Aquatic Sci., 48, 2276-2284.

Taghon, G.L., A.R.M. Nowell and R.A. Jumars, 1980: Induction of suspension feeding in spionid polychaetes by high particate fluxes. Science, 210, 562-564. 